\title{
PENGARUH ATRIBUT PRODUK TERHADAP KEPUASAN PELANGGAN PRODUK TEH CELUP SOSRO DAN 2 TANG \\ (Survei Pada Pelanggan Teh Celup di Griya Pahlawan dan Giant Pasteur Bandung)
}

Oleh:

Dian H. Utama

Fitri Amelia

\begin{abstract}
Abstrak
Persaingan diberbagai bidang industri semakin ketat, salah satunya industri minuman yang terus menerus berkembang. Menghadapi era globalisasi, dunia bisnis harus dapat meningkatkan kinerja dari suatu bisnis sehingga mampu bertahan dan bersaing. Sejalan dengan adanya perubahan di berbagai sektor ekonomi, teknologi, politik dan kondisi dari suatu pasar yang semakin terlihat jelas. Secara langsung ataupun tidak langsung adanya perubahan di bidang ekonomi dan kondisi sosial sekarang ini telah pula merubah sikap dan tingkah laku konsumen. Pemilihan akan suatu produk menjadi pilihan utama dalam pemasaran, konsumen tidak hanya melihat dari segi merek atau promosi yang bagus dan menarik tetapi kualitas produk pun menjadi pilihan. Persaingan dalam industri teh mengakibatkan merek Teh Celup Sosro dan 2 Tang mengalami penurunan dalam tingkat kepuasan pelanggan. Dalam menghadapi persoalan ini, perusahaan Teh Celup Sosro dan 2 Tang melakukan berbagai inovasi dan kualitas produk. Atribut produk merupakan unsur-unsur produk yang dipandang penting oleh konsumen dan dijadikan dasar pengambilan keputusan pembelian, sehingga akhirnya konsumen menjadi puas akan kinerja produk. Berdasarkan hal tersebut, penelitian ini untuk melihat pengaruh atribut produk terhadap kepuasan pelanggan. Penelitian ini bersifat deskriptif-verivikatif dan metode yang digunakan dalam penelitian ini adalah explanatory survei dan deskriptif survei. Objek yang diteliti adalah pelanggan Teh Celup Sosro dan 2 Tang di Griya Pahlawan dan Giant Pasteur Bandung, dengan jumlah sampel sebanyak 90 orang (57 orang pelanggan Teh Celup Sosro dan 33 pelanggan 2 Tang) yang diambil dengan metode sistematik random sampling. Teknik analisis yang digunakan adalah regresi linier sederhana. Adapun hipotesis dari penelitian ini adalah terdapat pengaruh yang positif antara atribut produk terhadap kepuasan pelanggan.
\end{abstract}

\section{PENDAHULUAN}

Industri makanan dan minuman berkembang kian pesat seiring dengan perubahan ilmu pengetahuan dan teknologi serta perekonomian, dimana hal ini sejalan dengan peningkatan kebutuhan, keinginan dan harapan konsumen akan arti kesehatan. Berkembangnya bisnis makanan dan minuman khususnya produk terlihat dari banyaknya produk dengan berbagai merek di Indonesia, baik produk dalam negeri maupun produk luar negeri.

Persaingan pada bidang industri ini menjadikan salah satu peluang dan tantangan bagi perusahaan sebagai produsen untuk terus memproduksi produk yang berkualitas, bervariasi dan dapat bersaing dengan produk-produk impor serta untuk mempertahankan eksistensi perusahaannya di masa yang akan datang. Dilihat dari Brand value tahun 2006 industri makanan dan minuman memberikan peluang pasar yang luas dan besar. Secara jelas disajikan pada Tabel berikut.

Tabel 1

Nilai Brand Value Industri Di Indonesia

\begin{tabular}{|c|l|c|}
\hline No. & \multicolumn{1}{|c|}{ Bidang Industri } & Brand Value \\
\hline 1 & Hp dan Simcard & 629,00 \\
\hline 2 & Makanan dan Minuman & 610,00 \\
\hline 3 & Toiletris & 588,00 \\
\hline 4 & Obat & 588,00 \\
\hline 5 & Jasa Penerbangan & 541,00 \\
\hline 6 & Suplemen/Multivitamin & 331,00 \\
\hline 7 & Bank & 313,00 \\
\hline 8 & Kosmetik & 248,00 \\
\hline 9 & Asuransi & 215,00 \\
\hline 10 & Media & 198,00 \\
\hline 11 & Perlengkapan OR & 153,00 \\
\hline 12 & Kartu kredit & 108,00 \\
\hline
\end{tabular}

Sumber: SWA 15/XX/21 Juli - 3 Agustus 2006 
Berdasarkan Tabel diatas menunjukkan bahwa kinerja yang terbesar di tempati oleh $\mathrm{Hp}$ dan Simcard, sedangkan industri makanan dan minuman berada di bawahnya dengan nilai 610,0 . Ini memberikan peluang bagi para pelaku bisnis makanan dan minuman untuk lebih inovatif dalam meningkatkan kinerjanya di tengah persaingan para pelaku bisnis makanan dan minuman.

Salah satu produk dari industri minuman yang ditawarkan adalah produk teh celup. Persaingan teh celup pada saat ini semakin ketat karena adanya berbagai merek, varian pilihan rasa teh yang beredar di pasar, berbagai ukuran kemasan yang dapat memudahkan konsumen untuk membeli sesuai keinginan serta kemenarikan kemasan yang ditampilkan. Lihat Tabel 1.2.

TABEL 2

TEH BERMEREK DI INDONESIA

\begin{tabular}{|c|l|l|}
\hline No & \multicolumn{1}{|c|}{ Merek } & \multicolumn{1}{c|}{ Perusahaan } \\
\hline 1 & Teh Sariwangi & PT Unilever Tbk \\
\hline 2 & Teh Sosro & PT Gunung Selamet \\
\hline 3 & Teh 2 Tang & PT Duta Serpak Inti \\
\hline 4 & Teh Bendera & PT Pematang Siantar \\
\hline 5 & Teh Poci & PT Gunung Selamet \\
\hline 6 & Teh Upet & PT Gunung Selamet \\
\hline 7 & Teh Tongtji & PT Dua Burung Faktory \\
\hline 8 & Teh Tjatoet & PT Duta Serpak Inti \\
\hline 9 & $\begin{array}{l}\text { Teh Kepala } \\
\text { Djenggot }\end{array}$ & PT Gunung Subur \\
\hline 10 & Teh Walini & $\begin{array}{l}\text { PT Perkebunan Nusantara } \\
\text { VIII }\end{array}$ \\
\hline
\end{tabular}

Sumber: Hasil Pra Penelitian 2007

Dari berbagai merek teh celup, hanya lima merek yang merupakan pemain utama dalam produk teh celup yaitu Teh Sariwangi, Teh Sosro, Teh Poci, Teh 2 Tang dan Teh Bendera. Persaingan terjadi pada lima merek tersebut. Khusus untuk Teh Celup Sariwangi menguasai pasar teh celup sebesar $80 \%$ (MarketinglEdisi Khusus II2007). Tingginya tingkat kemampuan pemasar dalam memberikan nilai pada produknya dan bagaimana produk tersebut menghadirkan pengalaman konsumen yang mengesankan akan berpengaruh pada kepuasan konsumen.

Persaingan yang ketat di dalam bisnis teh celup membuat pengusaha bisnis ini terus mengembangkan dan meningkatkan kinerja perusahaannya, agar produknya mampu bersaing. Apalagi bagi masyarakat Indonesia minum teh sudah merupakan suatu budaya, karena teh merupakan minuman yang banyak dikonsumsi oleh orang tua dan kalangan muda. Anak-anak muda sekarang ini sudah tahu minuman yang sehat. Mereka mulai meninggalkan minuman soft drink, dengan membiasakan minum minuman sehat, misalnya teh. Sebagai contoh yang bisa di lihat, di rumah makan, yang namanya pesanan es lemon tea dan teh manis panas atau pun dingin, sudah mulai mendominasi dibandingkan dengan soft drink.

Di bawah ini disajikan Tabel mengenai kepuasan pelanggan terhadap produk teh celup.

Tabel 3

Indeks Tingkat Kepuasan Pelanggan Terhadap

\begin{tabular}{|c|c|c|c|c|c|c|c|c|c|}
\hline \multirow[t]{2}{*}{ Merek } & \multicolumn{2}{|c|}{ QSS } & \multicolumn{2}{|c|}{ VSS } & \multicolumn{2}{|c|}{ PBS } & \multicolumn{2}{|c|}{ TSS } & \multirow{2}{*}{$\begin{array}{c}\text { Pertumbu } \\
\text { han }(\%)\end{array}$} \\
\hline & 2005 & 2006 & 2005 & 2006 & 2005 & 2006 & 2005 & 2006 & \\
\hline Sariwangi & 4.557 & 4.595 & 3.972 & 4.395 & 4.523 & 4.584 & 4.336 & 4.451 & 0.12 \\
\hline Sosro & 3.877 & 3.791 & 3.798 & 3.724 & 3.909 & 3.759 & 3.859 & 3.681 & -0.18 \\
\hline 2 Tang & 3.725 & 3.654 & 3.787 & 3.649 & 3.761 & 3.615 & 3.759 & 3.568 & $-0,19$ \\
\hline Poci & 3.758 & 3.892 & 3.905 & 3.872 & 3.825 & 3.867 & 3.833 & 3.785 & -0.05 \\
\hline Bendera & 3.682 & 3.995 & 3.521 & 4.004 & 3.633 & 3.964 & 3.567 & 3.921 & 0.35 \\
\hline Tongtji & - & 3.789 & - & 3.613 & 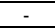 & 3.648 & - & 3.624 & - \\
\hline
\end{tabular}

Sumber: SWA 19/XXI/15-28 September 2005 dan SWA 20/XXII/21 September- 4 Oktober 2006

Dari Tabel diatas terlihat bahwa Teh Celup Sosro pada tahun 2006 mengalami penurunan akan kepuasan produk, penurunan terjadi pada semua kategori baik QSS, VSS, maupun PBS dengan penurunan sebesar $-0,18 \%$. Untuk merek 2 Tang juga mengalami penurunan kepuasan produk pada semua kategori di mana penurunan Teh Celup 2 Tang ini sebesar $-0,19 \%$ lebih besar dari yang dialami Teh Celup Sosro. Untuk Teh Celup Bendera dapat kita lihat mengalami pertumbuhan yang cukup tinggi di semua kategori pada tahun 2006.

Penurunan peringkat nilai kepuasan pelanggan terhadap produk Teh Celup Sosro dan 2 Tang menunjukkan bahwa kinerja dari produk ini belum sepenuhnya mampu memberikan kepuasan bagi para konsumennya. Melihat fenomena seperti ini maka menuntut perusahaan Teh Celup Sosro dan 2 Tang untuk melakukan berbagai strategi pemasaran yang mampu meningkatkan kepuasan serta mempertahankan loyalitas para pelanggannya. Berbagai cara dapat dilakukan untuk mempertahankan kepuasan pelanggan di antaranya, menetapkan harga yang bersaing dan peningkatan atribut produk seperti kualitas, fitur serta desain produk. Craven (2003 :9) berpendapat bahwa kepuasan dipengaruhi oleh identifikasi atribut produk baik secara pengiriman 
produk, performa produk atau jasa, citra perusahaan atau produk atau merek, nilai harga yang dihubungkan dengan nilai yang diterima konsumen.

Salah satu cara yang dilakukan perusahaan Teh Celup Sosro dan 2 Tang untuk mempertahankan kepuasan pelanggan di antaranya yaitu dengan peningkatan atribut produk mulai dari kualitas, fitur serta desain dari produk teh celup itu sendiri yang diberikan kepada para konsumen dan pelanggannya. Inovasi-inovasi yang harus dilakukan Sosro dan 2 Tang yaitu dengan menciptakan produk teh celup yang sesuai dengan kebutuhan dan keinginan konsumen, seperti memproduksi berbagai rasa teh mulai dari teh hitam yang merupakan rasa teh asli, lalu teh hijau yang berguna untuk menurunkan berat badan, serta memproduksi teh wangi melati atau teh yang beraroma wangi melati pada saat diminum. Untuk desain produk, bentuk kemasan di buat semenarik mungkin dengan warna-warna yang cerah dan gambar yang sesuai dengan produk.

Tingkat kepuasan menunjukkan pandangan pelanggan akan produk yang akan dibeli dan digunakannya lagi, dengan pelanggan puas akan produk dengan merek yang sama maka besar kemungkinan pelanggan melakukan pembelian kembali produk dengan merek yang sama. Pengguna produk teh celup melakukan suatu keputusan di dalam membeli sebuah produk dipengaruhi oleh berbagai faktor. Faktor-faktor yang dipertimbangkan terdiri dari kualitas produk, fitur produk, dan desain/kemasan produk yang ditunjukkan lewat atribut sebuah produk.

Adanya atribut produk yang diberikan terhadap produk maka akan mampu menarik konsumen untuk melakukan keputusan pembelian dan diharapkan konsumen akan puas menggunakan produk sehingga mereka akan loyal dan menjadi pelanggan setia.

Berdasarkan latar belakang di atas maka diperlukan untuk mengadakan suatu penelitian tentang "Pengaruh Atribut Produk terhadap Kepuasan Pelanggan Produk Teh Celup Sosro dan 2 Tang" (Survei pada pelanggan Teh Celup di Griya Pahlawan dan Giant Pasteur Bandung).

\section{KERANGKA PEMIKIRAN}

Bauran pemasaran (marketing mix) atau yang lebih dikenal dengan 4P (Product, Place, price, Promotion) merupakan suatu komponen yang harus mendapat perhatian oleh setiap perusahaan. Produk merupakan titik sentral atau bagian paling mendasar dalam kegiatan pemasaran, karena produk merupakan penawaran yang nyata pada pasar. Keputusan-keputusan yang berkaitan dengan produk dapat dijadikan instrumen oleh perusahaan dalam kegiatan pemasaran produknya, dan mempunyai tujuan untuk mengkomunikasikan produk yang sesuai dimata konsumen. Produk didefinisikan oleh William J. Stanton yang dikutip Buchari Alma (2004:139) adalah

"Seperangkat atribut baik berwujud maupun tidak berwujud termasuk di dalamnya warna, harga, nama baik produk, nama baik toko yang menjual (pengecer) dan pelayanan pabrik serta pelayanan pengecer yang diterima oleh pembeli untuk memuaskan keinginannya".

Atribut produk mempunyai peranan yang penting dalam menciptakan kepuasan pelanggan, konsumen memandang produk merupakan himpunan atribut dengan kemampuan beragam, dalam hal ini memberikan manfaat yang dicari dan memuaskannya. Dengan produk yang memiliki kualitas, fitur serta rancangan (desain) yang baik maka akan mendorong konsumen untuk membeli produk tersebut dan merasa puas. Menurut Kotler\&Amstrong (2005:354), Atribut merupakan pengembangan suatu produk atau jasa yang melibatkan penentuan manfaat yang akan diberikan.

Atribut produk memiliki pengaruh yang besar terhadap reaksi konsumen atas suatu produk dan atribut produk merupakan stimulus bagi pembentukan perilaku konsumen. Pentingnya atribut, didefinisikan sebagai penilaian umum seseorang terhadap signifikansi atribut atas produk dan jasa jenis tertentu. Oleh karena itu, perusahaan dituntut agar menciptakan dan menghasilkan produk yang dapat memenuhi seluruh harapan konsumen, sehingga produk tersebut akan terus dikonsumsi.

Kotler dan Amstrong (2006:225), mengemukakan bahwa perusahan menciptakan kepuasan dan nilai bagi konsumen secara konsisten dan secara menguntungkan memenuhi kebutuhan dan keinginan konsumen. Kualiatas produk merupakan kemampuan produk untuk melakukan fungsi-fungsinya yang dapat mendukung posisi produk di pasar. Fitur merupakan alat persaingan untuk 
mendiferensiasikan produk perusahaan terhadap produk sejenis yang menjadi pesaingnya. Sedangkan dengan desain yang baik dapat menarik perhatian, meningkatkan kinerja produk, memotong biaya produksi, dan memberikan keunggulan bersaing di pasar sasaran.

Supranto (2002:25) menyatakan bahwa "pelanggan lebih memilih produk yang dibuat secara baik dan memiliki sederet fitur, keuntungan (benefit), dan jasa yang ditampilkan secara tepat sehingga pelanggan ini akan loyal/setia pada produk/jasa tersebut.

Setelah melakukan pembelian, maka konsumen akan mengalami suatu tingkatan kepuasan atau ketidakpuasan. Kepuasan konsumen menunjukan seberapa dekat harapan konsumen atas produk yang ditawarkan dan apa yang dirasakan dari produk tersebut yang diwakili atribut produk.

Dalam memilih produk, konsumen mengharapkan kepuasan yang akan diperolehnya dari produk atau merek yang dibelinya. Menurut Day dalam Fandy Tjiptono (2002:146)

"Kepuasan atau ketidakpuasan pelanggan adalah respon pelanggan terhadap evaluasi ketidaksesuaian/diskonfirmasi yang dirasakan antara harapan sebelumnya dan kinerja aktual produk yang dirasakan setelah pemakaian".

Jika harapan kinerja sebelum membeli lebih besar daripada kinerja yang diterima setelah membeli, maka dikatakan konsumen mengalami ketidakpuasan sebaliknya jika harapan lebih kecil dari persepsi kinerja yang setelah diterima, maka konsumen mengalami kepuasan.

Menurut Freddy Rangkuty (2003:23), "Kepuasan pelanggan adalah perasaan senang atau kecewa seseorang sebagai hasil dari perbandingan antara produk yang dirasakan dan yang diharapkan".

Ratih Huriyati (2005:125), menyatakan bahwa pelanggan yang memiliki loyalitas merasakan adanya ikatan emosional dengan perusahaan. Untuk meningkatkan loyalitas, perusahaan harus meningkatkan kepuasan pelanggan dan mempertahankan tingkat kepuasan tersebut dalam jangka panjang. Dalam hal ini perusahaan harus memberikan nilai tambah yang dapat membuat pelanggan mendapatkan apa yang mereka harapkan sehingga mereka akan terus bertahan dan mengarah pada pembelian ulang, merekomendasikan kepada orang lain, serta proposisi pembelian yang meningkat.

Harapan pelanggan berkembang dari waktu ke waktu, sesuai perkembangan dan perubahan yang terjadi. Kepuasan merupakan persepsi kesan atas kinerja dan harapan. Jika kinerja di bawah harapan, pelanggan akan tidak puas. Jika kinerja memenuhi harapan, pelanggan akan puas.

Berdasarkan gambar kerangka pemikiran di atas dapat diuraikan bahwa atribut produk merupakan alat yang digunakan perusahaan untuk menciptakan kepuasan pelanggan.

Dari uraian tersebut, maka dalam penelitian ini terdapat 2 variabel yang terdiri dari satu variabel bebas dan satu variabel terikat, yaitu Atribut Produk $(X)$, terhadap Kepuasan Pelanggan (Y). Paradigma penelitian merupakan pola pikir yang menunjukan hubungan antara variabel yang akan diteliti yang sekaligus mencerminkan

Jenis dan jumlah rumusan masalah yang perlu dijawab melalui penelitian, teori yang digunakan untuk merumuskan hipotesis, jenis dan jumlah hipotesis, dan teknik analisis statistik yang akan digunakan. Berdasarkan hal ini maka bentuk paradigma atau model dalam penelitian ini sebagai berikut :

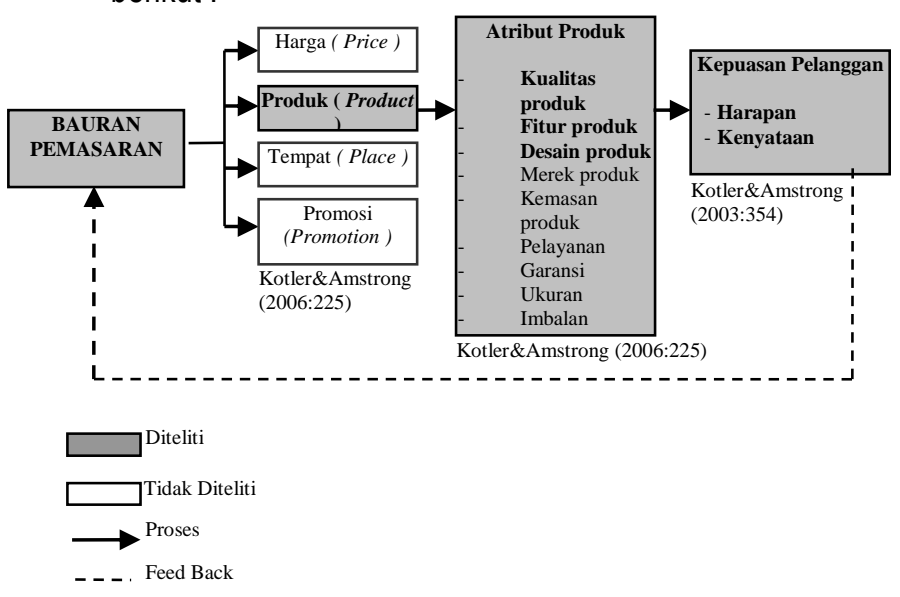

GAMBAR 1.1

KERANGKA PEMIKIRAN

Pengaruh Atribut Produk Terhadap Kepuasan

Pelanggan Produk Teh Celup Sosro dan 2 Tang

Berdasarkan kerangka pemikiran di atas, maka penulis mengemukakan paradigma penelitian sebagai berikut: 


\section{StrategiC}

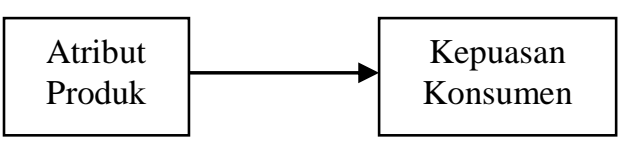

GAMBAR 1.2

PARADIGMA PENELITIAN

Pengaruh Atribut Produk Terhadap Kepuasan

Pelanggan Produk Teh Celup Sosro dan 2 Tang

III. METODE PENELITIAN

Penelitian ini menganalisis mengenai pengaruh atribut produk terhadap kepuasan pelanggan produk teh celup Sosro, dan 2 Tang. Adapun yang menjadi objek dalam penelitian sebagai variabel bebas (independent variable) atau disebut juga variabel eksogen adalah atribut produk $(X)$ yang terdiri dari kualitas produk, fitur produk, dan desain produk. Sedangkan objek yang merupakan variabel terikat (dependent variable) atau disebut juga variabel endogen adalah kepuasan pelanggan (Y) yang terdiri dari harapan dan kenyataan yang diperoleh.

Objek yang dijadikan responden adalah pelanggan teh celup Sosro, dan 2 Tang di Griya Pahlawan dan Giant Pasteur Bandung. Dari objek penelitian ini, maka akan dianalisis mengenai pengaruh atribut produk terhadap kepuasan pelanggan produk Teh Celup Sosro dan 2 Tang.

Berdasarkan variabel-variabel yang diteliti maka jenis penelitian ini adalah penelitian deskriptif dan verifikatif.

Berdasarkan jenis penelitian di atas yaitu penelitian deskriptif dan verifikatif yang dilakukan melalui pengumpulan data di lapangan, maka metode penelitian yang digunakan adalah metode deskriptif survey dan explanatory survey. Adapun penelitian ini dilakukan dalam jangka waktu kurang dari satu tahun, yaitu mulai dari bulan Agustus sampai bulan Januari 2008 , oleh karena itu metode penelitian yang digunakan adalah cross sectional method yaitu metode penelitian dengan cara mempelajari objek dalam satu kurun waktu tertentu (tidak berkesinambungan dalam jangka waktu panjang). (Husein Umar, 2002:45)

\section{Operasionalisasi Variabel}

Berdasarkan objek penelitian yang telah dikemukakan di atas dapat diketahui bahwa variabel yang dikaji dalam penelitian ini adalah atribut produk sebagai variabel bebas $(X)$ yang terdiri dari kualitas produk, fitur produk, dan desain produk. Dari variabel bebas $(X)$ tersebut dicari bagaimana pengaruhnya terhadap kepuasan pelanggan sebagai variabel terikat $(Y)$. Secara rinci uraian operasionalisasi variabel dapat terlihat dalam Tabel berikut ini :

Tabel 4

Operasionalisasi Variabel

\begin{tabular}{|c|c|c|}
\hline Variabel & Indikator & Ukuran \\
\hline \multirow{10}{*}{$\begin{array}{l}\text { Atribut Produk } \\
\quad(\mathrm{X}) \\
\text { Atribut produk } \\
\text { merupakan } \\
\text { pengembangan } \\
\text { suatu produk } \\
\text { atau jasa yang } \\
\text { melibatkan } \\
\text { penentuan } \\
\text { manfaat yang } \\
\text { akan diberikan } \\
\text { (Kotler\&Amst } \\
\text { rong } \\
\text { 2006:226) }\end{array}$} & \multirow{4}{*}{$\begin{array}{|ll|}\text { 1. } & \text { Kualitas } \\
& \text { Produk }\end{array}$} & 1) Tingkat kualitas rasa \\
\hline & & $\begin{array}{l}\text { 2) Tingkat daya tahan produk } \\
\text { yang di jual }\end{array}$ \\
\hline & & $\begin{array}{l}\text { 3) Tingkat kualitas warna } \\
\text { seduhan }\end{array}$ \\
\hline & & $\begin{array}{l}\text { 4) Tingkat kekuatan aroma } \\
\text { produk }\end{array}$ \\
\hline & \multirow{3}{*}{ 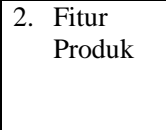 } & 5) Tingkat kekhasan rasa \\
\hline & & $\begin{array}{l}\text { 6) Tingkat kekhasan warna dan } \\
\text { aroma }\end{array}$ \\
\hline & & 7) Tingkat variasi rasa produk \\
\hline & \multirow[t]{3}{*}{$\begin{array}{ll}\text { 3. } & \text { Desain } \\
& \text { Produk }\end{array}$} & $\begin{array}{l}\text { 8) Tingkat daya tarik } \\
\text { rancangan kemasan } \\
\text { produk }\end{array}$ \\
\hline & & $\begin{array}{l}\text { 9) Tingkat ukuran kemasan } \\
\text { produk }\end{array}$ \\
\hline & & 10) $\begin{array}{l}\text { Tingkat kemudahan } \\
\text { mengkonsumsi produk }\end{array}$ \\
\hline \multirow{7}{*}{$\begin{array}{c}\text { Kepuasan } \\
\text { Pelanggan } \\
\text { (Y) } \\
\text { Perasaan } \\
\text { seseorang } \\
\text { setelah } \\
\text { membandingk } \\
\text { an kinerja } \\
\text { (atau hasil) } \\
\text { yang dia } \\
\text { rasakan } \\
\text { dibandingkan } \\
\text { dengan } \\
\text { harapannya. } \\
\text { (Philip Kotler } \\
\text { dan A.B } \\
\text { Susanto } \\
\text { (2004:52 }\end{array}$} & \multirow[t]{4}{*}{$\begin{array}{l}\text { Harapan dan } \\
\text { Kinerja dari } \\
\text { Atribut } \\
\text { Produk }\end{array}$} & $\begin{array}{l}\text { 1)a. Tingkat harapan terhadap } \\
\text { kualitas rasa } \\
\text { b. Tingkat kenyataan yang } \\
\text { dirasakan terhadap } \\
\text { kualitas rasa }\end{array}$ \\
\hline & & 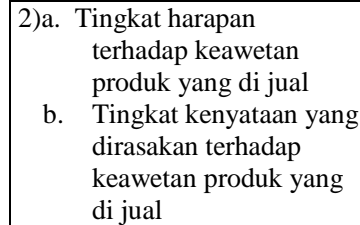 \\
\hline & & $\begin{array}{l}\text { 3)a. Tingkat harapan terhadap } \\
\text { kualitas warna seduhan } \\
\text { b. Tingkat kenyataan yang } \\
\text { dirasakan terhadap } \\
\text { kualitas warna seduhan } \\
\end{array}$ \\
\hline & & $\begin{array}{l}\text { 4)a. Tingkat harapan terhadap } \\
\text { kekuatan aroma } \\
\text { b. Tingkat kenyataan yang } \\
\text { dirasakan terhadap } \\
\text { kekuatan aroma } \\
\end{array}$ \\
\hline & \multirow[t]{3}{*}{$\begin{array}{l}\text { Harapan dan } \\
\text { Kinerja dari } \\
\text { Fitur Produk }\end{array}$} & 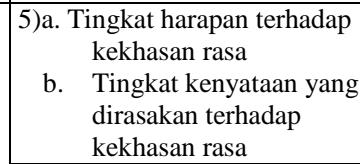 \\
\hline & & $\begin{array}{l}\text { 6)a. Tingkat harapan terhadap } \\
\text { kekhasan warna dan } \\
\text { aroma } \\
\text { b. Tingkat kenyataan yang } \\
\text { dirasakan terhadap } \\
\text { kekhasan warna dan } \\
\text { aroma }\end{array}$ \\
\hline & & 7)a. Tingkat harapan terhadap \\
\hline
\end{tabular}

34-95 


\begin{tabular}{|c|c|}
\hline & $\begin{array}{l}\text { variasi rasa produk } \\
\text { b. Tingkat kenyataan yang } \\
\text { dirasakan terhadap } \\
\text { variasi rasa produk } \\
\end{array}$ \\
\hline \multirow[t]{3}{*}{$\begin{array}{l}\text { Harapan dan } \\
\text { Kinerja dari } \\
\text { Desain } \\
\text { Produk }\end{array}$} & $\begin{array}{l}\text { 8)a. Tingkat harapan terhadap } \\
\text { daya tarik rancangan } \\
\text { kemasan produk } \\
\text { b. Tingkat kenyataan yang } \\
\text { dirasakan terhadap } \\
\text { daya tarik rancangan } \\
\text { kemasan produk }\end{array}$ \\
\hline & 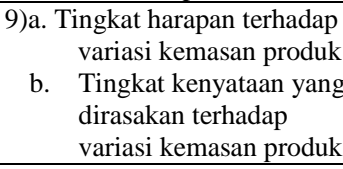 \\
\hline & $\begin{array}{l}\text { 10)a.Tingkat harapan } \\
\text { terhadap kemudahan } \\
\text { mengkonsumsi produk } \\
\text { b. Tingkat kenyataan yang } \\
\text { dirasakan terhadap } \\
\text { kemudahan } \\
\text { mengkonsumsi produk }\end{array}$ \\
\hline
\end{tabular}

Populasi

Pelaksanaan penelitian tidak akan lepas dari objek yang akan diteliti karena melalui objek tersebut akan diperoleh variabel-variabel yang merupakan permasalahan dalam penelitian dan diperoleh suatu pemecahan-pemecahan masalah yang akan menunjang keberhasilan penelitian.

Populasi sasaran dari penelitian ini adalah pelanggan Teh Celup Sosro dan 2 Tang di Griya Pahlawan dan Giant Pasteur Bandung.

Penentuan populasi dalam penelitian ini adalah pelanggan Teh Celup Sosro dan 2 Tang di Griya Pahlawan dan Giant Pasteur yang rata-rata pengunjung per hari berjumlah 300 sampai 400 orang melalui wawancara dengan pegawai dari masing-masing Supermarket. Berdasarkan hasil pelaksanaan penelitian di Griya Pahlawan dan Giant Pasteur diperoleh populasi berukuran 904 orang.

\section{Sampel}

Pada penelitian ini kita tidak perlu meneliti seluruh populasi, tetapi mengambil sampel yakni sebagian dari populasi yang dianggap mewakili seluruh populasi. Dalam menentukan jumlah sampel digunakan pengambilan sampel dengan menggunakan simple random sampling dari Harun Al Rasyid (1994:44), yaitu :

$$
n=\frac{n_{0}}{1+\frac{n_{0}}{N}}
$$

Berdasarkan perhitungan, maka ukuran sampel minimal yang digunakan dalam penelitian sebesar 88 orang responden. Menurut Winarno Surakhmad (1998:100) bahwa "Untuk jaminan ada baiknya sampel selalu ditambah sedikit lagi dari jumlah matematik ". Sehingga agar sampel dalam penelitian ini bagus sampelnya ditambah sebanyak 2 orang dan menjadi 90 orang responden.

\section{Teknik Sampling}

Sampling dilakukan oleh peneliti untuk mengumpulkan data. Untuk menentukan besarnya ukuran sampel yang akan diteliti, maka harus digunakan teknik sampling. Berikut Tabel Penyebaran aproposal sampel.

Tabel 5

Penyebaran Proporsi Sampel

\begin{tabular}{|c|c|l|c|}
\hline $\begin{array}{c}\text { Merek } \\
\text { Teh } \\
\text { Celup }\end{array}$ & $\begin{array}{c}\text { Jumlah } \\
\text { Populasi }\end{array}$ & \multicolumn{1}{|c|}{ Sampel } & Jumlah \\
\hline Sosro & 577 & $\begin{array}{l}577 / 904 \times 90= \\
57,44\end{array}$ & 57 \\
\hline 2 Tang & 327 & $\begin{array}{l}327 / 904 \times 90= \\
32,55\end{array}$ & 33 \\
\hline Jumlah & 904 & & 90 \\
\hline
\end{tabular}

Sumber: Penelitian 2007

\section{Teknis Analisis Data}

Dalam penelitian ini menggunakan metode pengukuran Path Analisys.

\section{HASIL PENELITIAN DAN PEMBAHASAN}

\subsection{Gambaran Atribut Produk}

Berdasarkan penelitian dengan menyebarkan angket kepada 90 responden, 57 responden Teh Celup Sosro dan 33 responden Teh Celup 2 Tang dan perhitungan dengan menggunakan SPSS, dapat diketahui gambaran mengenai variabel atribut produk $(X)$. Adapun yang paling dominan dapat dilihat dalam tabel berikut ini. 
TABEL 6

REKAPITULASI INDIKATOR ATRIBUT PRODUK TEH CELUP SOSRO DAN 2 TANG

\begin{tabular}{|c|c|c|c|c|c|c|c|}
\hline \multirow{2}{*}{ No. } & \multirow{2}{*}{ Indikator } & \multicolumn{2}{|c|}{ Teh Celup Sosro } & \multirow{2}{*}{$\%$} & \multicolumn{2}{|c|}{$\begin{array}{l}\text { Teh Celup } \\
2 \text { Tang }\end{array}$} & \multirow{2}{*}{$\%$} \\
\hline & & Skor & $\begin{array}{l}\text { Skor } \\
\text { Ideal }\end{array}$ & & Skor & $\begin{array}{l}\text { Skor } \\
\text { Ideal }\end{array}$ & \\
\hline \multirow[t]{6}{*}{1} & Kualitas Produk & & & & & & \\
\hline & - Kualitas rasa & 232 & 285 & 81,40 & 129 & 165 & 78,18 \\
\hline & - Daya tahan produk & 217 & 285 & 76,14 & 134 & 165 & 81,12 \\
\hline & - Kualitas warna seduhan & 224 & 285 & 78,59 & 136 & 165 & 82,42 \\
\hline & - Aroma produk & 224 & 285 & 78,59 & 125 & 165 & 75,75 \\
\hline & Total Skor Kualitas Produk & 897 & 1140 & 78,68 & 524 & 660 & 79,39 \\
\hline \multirow[t]{5}{*}{2} & Fitur Produk & & & & & & \\
\hline & $\begin{array}{l}\text { - Memiliki rasa yang berbeda } \\
\text { dari merek lain }\end{array}$ & 243 & 285 & 85,26 & 139 & 165 & 84,24 \\
\hline & $\begin{array}{l}\text { - Memiliki warna air seduhan } \\
\text { yang berbeda }\end{array}$ & 249 & 285 & 87,36 & 133 & 165 & 80,60 \\
\hline & $\begin{array}{l}\text { - Terdapat rasa produk yang } \\
\text { bervariasi }\end{array}$ & 243 & 285 & 85,26 & 136 & 165 & 82,42 \\
\hline & Total Skor Fitur Produk & 735 & 855 & 85,96 & 408 & 495 & 82,42 \\
\hline \multirow[t]{6}{*}{3} & Desain Produk & & & & & & \\
\hline & - Bentuk kemasan produk & 246 & 285 & 86,31 & 141 & 165 & 84,84 \\
\hline & - Ukuran kemasan produk & 245 & 285 & 85,96 & 139 & 165 & 84,24 \\
\hline & - Cara mengkonsumsi produk & 218 & 285 & 76,49 & 142 & 165 & 89,09 \\
\hline & Total Skor Desain Produk & 709 & 855 & 82,92 & 422 & 495 & 85,25 \\
\hline & Total Skor Atribut Produk & 2341 & 2850 & 82,14 & 1354 & 1650 & 82,06 \\
\hline
\end{tabular}

Berdasarkan Tabel diatas mengenai gambaran atribut produk Teh Celup Sosro secara keseluruhan dinilai cukup kuat yaitu sebesar $82,14 \%$, secara berurutan dapat diketahui indikator-indikator atribut yang dominan. Indikator yang paling dominan adalah fitur produk yaitu sebesar $85,96 \%$, indikator tertinggi kedua adalah desain produk yaitu sebesar $82,92 \%$, dan indikator paling rendah adalah kualitas produk dengan memperoleh presentase skor sebesar $78,68 \%$.

Selanjutnya gambaran atribut produk dari Teh Celup 2 Tang secara keseluruhan dinilai kuat yaitu sebesar $82,06 \%$ secara berurutan dapat diketahui indikator-indikator atribut yang dominan. Indikator yang paling dominan adalah desain produk yaitu sebesar $85,25 \%$, indikator dominan kedua adalah fitur produk sebesar $82,42 \%$ dan yang paling rendah adalah kualitas produk sebesar $79,39 \%$.

Hasil tersebut menunjukkan bahwa tingkat fitur produk dari Teh Celup Sosro dan 2 Tang yang dinilai oleh pelanggannya dapat dikatakan sangat tinggi, karena fitur produk yang terdiri dari kekhasan rasa, kekhasan warna dan variasi rasa sesuai dengan yang diharapkan oleh konsumen sebagai pelanggan, maka dari itu kekhasan rasa dan warna dari Teh Celup Sosro dan 2 Tang tidak sama dengan merek teh lainnya. Ini berarti bahwa Teh Celup Sosro dan 2 Tang telah disukai atau digemari oleh pelanggannya dengan berbagai karakteristik dan keistimewaan yang dimilikinya sehingga akan dapat terus meningkat posisinya di masa yang akan datang.

$\mathrm{Hal}$ ini sesuai dengan yang diungkapkan oleh Kotler dan Amstrong (2006:226), Fitur adalah alat untuk barsaing yang membedakan produk suatu perusahan dengan produk lainnya. Fitur produk identik dengan sesuatu yang unik, khas, dan istimewa yang tidak dimiliki oleh produk lainnya.

\subsection{Gambaran Kepuasan Pelanggan}

Berdasarkan penelitian dengan menyebarkan angket kepada 90 responden, 57 responden Teh Celup Sosro dan 33 responden teh celup 2 Tang, 
dapat diketahui gambaran mengenai variabel kepuasan pelanggan $(Y)$ yang paling dominan dapat dilihat dalam tabel berikut ini.

TABEL 7

REKAPITULASI INDIKATOR KEPUASAN PELANGGAN TEH CELUP SOSRO

\begin{tabular}{|c|c|c|c|c|c|c|c|}
\hline \multirow{2}{*}{ No. } & \multirow{2}{*}{ Indikator } & \multicolumn{2}{|c|}{$\begin{array}{l}\text { Teh Celup } \\
\text { Sosro }\end{array}$} & \multirow{2}{*}{$\%$} & \multicolumn{2}{|c|}{$\begin{array}{l}\text { Teh Celup } \\
2 \text { Tang }\end{array}$} & \multirow{2}{*}{$\%$} \\
\hline & & Skor & $\begin{array}{l}\text { Skor } \\
\text { Ideal }\end{array}$ & & Skor & $\begin{array}{l}\text { Skor } \\
\text { Ideal }\end{array}$ & \\
\hline \multirow[t]{6}{*}{1} & Kualitas Produk & & & & & & \\
\hline & - Kualitas rasa & 226 & 285 & 79,30 & 120 & 165 & 72,72 \\
\hline & - Daya tahan produk & 241 & 285 & 84,56 & 130 & 165 & 78,78 \\
\hline & - Kualitas warna seduhan & 235 & 285 & 82,45 & 123 & 165 & 74,54 \\
\hline & - $\quad$ Aroma produk & 228 & 285 & 80 & 117 & 165 & 83,03 \\
\hline & Total Skor Kualitas Produk & 930 & 1140 & 81,57 & 490 & 660 & 74,24 \\
\hline \multirow[t]{5}{*}{2} & Fitur Produk & & & & & & \\
\hline & $\begin{array}{l}\text { - Memiliki rasa yang berbeda dari } \\
\text { merek lain }\end{array}$ & 249 & 285 & 87,37 & 135 & 165 & 81,81 \\
\hline & $\begin{array}{l}\text { - Memiliki warna air seduhan } \\
\text { yang berbeda }\end{array}$ & 230 & 285 & 80,70 & 129 & 165 & 78,18 \\
\hline & $\begin{array}{l}\text { - Terdapat rasa produk yang } \\
\text { bervariasi }\end{array}$ & 239 & 285 & 83,85 & 127 & 165 & 76,96 \\
\hline & Total Skor Fitur Produk & 718 & 855 & 83,97 & 391 & 495 & 78,99 \\
\hline \multirow[t]{6}{*}{3} & Desain Produk & & & & & & \\
\hline & - $\quad$ Bentuk kemasan produk & 248 & 285 & 87,02 & 131 & 165 & 79,39 \\
\hline & - Ukuran kemasan produk & 226 & 285 & 79,30 & 122 & 165 & 73,93 \\
\hline & - Cara mengkonsumsi produk & 251 & 285 & 88,07 & 139 & 165 & 84,24 \\
\hline & Total Skor Desain Produk & 725 & 855 & 84,79 & 392 & 495 & 79,19 \\
\hline & Total Skor Atribut Produk & 2373 & 2850 & 83,26 & 1273 & 1650 & 77,15 \\
\hline
\end{tabular}

Hasil tersebut menunjukkan bahwa tingkat desain produk dari Teh Celup Sosro dan 2 Tang yang dinilai oleh pelanggannya dapat dikatakan sangat tinggi, karena desain produk yang terdiri dari bentuk kemasan, ukuran kemasan, dan kemudahan mengkonsumsi sesuai dengan yang diharapkan oleh konsumen sebagai pelanggan, ini berarti bentuk dan ukuran kemasan dari Teh Celup Sosro dan 2 Tang dapat dikatakan menarik dan disukai oleh pelanggannya sehingga akan dapat terus meningkat posisinya di masa yang akan datang.

Desain produk memiliki konsep yang lebih luas dari gaya (style). Desain selain mementingkan faktor penampilan, juga bertujuan untuk memperbaiki kinerja produk, mengurangi biaya produksi, dan menambah keunggulan bersaing. Menurut Kotler (2005:332), mengartikan "Desain atau rancangan adalah totalitas keistimewaan yang mempengaruhi penampilan fungsi peroduk dari segi kebutuhan pelanggan". Desain yang baik dapat memberikan kontribusi dalam hal kegunaan dan juga penampilannya.

\subsection{Pengaruh Atribut Produk Terhadap Kepuasan Pelanggan Teh Celup Sosro}

Hasil perhitungan analisis data dari variabel atribut produk dan kepuasan pelanggan yang telah dilakukan, maka dapat diketahui bahwa 
atribut produk berpengaruh secara positif terhadap kepuasan pelanggan.

Dari hasil penelitian diperoleh angka koefisien korelasi 0,510 antara variabel atribut produk $(X)$ terhadap kepuasan pelanggan $(Y)$ memiliki hubungan yang termasuk kategori sedang (Sugiyono:2005:18). Selain itu, atribut produk memiliki pengaruh positif terhadap kepuasan pelanggan. Hal ini terbukti dengan hasil perhitungan koefisien determinasi yaitu dengan mengkuadratkan koefisien korelasi $\mathrm{r}^{2} \times 100 \%=$ $(0,510 \times 0,510) \times 100 \%$ diperoleh hasil sebesar 26 yang berarti bahwa perubahan variabel kepuasan pelanggan sebesar 26 dipengaruhi oleh atribut produk, sedangkan 74 dipengaruhi oleh faktor lain.

Adapun untuk mengetahui uji probabilitas atau uji pengambilan keputusan, maka dapat diketahui melalui tabel annova atau $\mathrm{F}$ test dimana $\mathrm{F}_{\text {hitung }}$ yaitu sebesar 19,325 (Tabel 4.48) dengan tingkat signifikansi sebesar 0,000 dan probabilitas $(0,000)$, sedangkan $F_{\text {tabel }}=4,396$ (Lampiran interpolasi) karena nilai $F_{\text {hitung }}>F_{\text {tabel }}$ maka dapat disimpulkan tolak $\mathrm{H}_{0}$. Artinya ada hubungan linier antara atribut produk terhadap kepuasan pelanggan. Hal ini dapat dilihat pada tabel sig 0,000 (Tabel 4.48) yang lebih kecil taraf signifikansi 5\%. Maka dapat dikatakan bahwa atribut produk berpengaruh terhadap kepuasan pelanggan. Walaupun demikian, jika pada proses uji koefisien regresi, ternyata konstanta dinyatakan tidak valid, maka koefisien regresi $(X)$ adalah valid, sehingga model persamaan regresi tetap dapat dipakai untuk memprediksi kepuasan pelanggan.

Pengambilan keputusan pengujin hipotesis dilakukan dengan membandingkan $t_{\text {hitung }}$ dengan

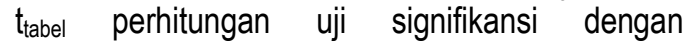
menggunakan alpha 0,05 pada uji satu pihak dengan derajat kebebasan (dk) n-2 maka dk $=55$ diperoleh thitung dan $t_{\text {tabel }}$ dengan taraf kesalahan 0,05 . Berdasarkan ketentuan hipotesis diterima jika thitung $>t_{\text {tabel }}$ maka diketahui bahwa harga thitung $>t_{\text {tabel }}(4,396>2,005)$ ( Tabel 4.47) sehingga dapat disimpulkan bahwa koefisien korelasi antara variabel atribut produk terhadap kepuasan pelanggan memiliki hubungan yang signifikan.

Pernyataan tersebut diperoleh melalui pengujian hipotesis yang menggunakan metode regresi linier sederhana, yang ditunjukkan dengan perolehan kepuasan pelanggan, dimana setiap penambahan 1 atribut produk akan meningkatkan kepuasan pelanggan yaitu sebesar 15,241 ditambah 0,524 dari atribut produk ( $Y=15,241+$ $0,524 \mathrm{X})$, dimana koefisien determinasi $\left(\mathrm{r}^{2}\right)$ yaitu 0,260 termasuk kategori rendah berada diantara $(0,20-0,399)$.

Koefisien korelasi yang bernili positif menunjukan bahwa jika perusahaan meningkatkan atribut produk maka dapat diprediksi bahwa kepuasan pelanggan juga akan naik. Namun, sebaliknya jika perusahaan tidak meningkatkan atribut produk maka kepuasan pelanggan bisa menurun.

Setelah melakukan pembelian, maka konsumen mengalami suatu tingkatan kepuasan atau ketidakpuasan. Kepuasan menunjukan seberapa dekat harapan konsumen atas produk yang ditawarkan dan apa yang dirasakan dari produk tersebut yang diwakili oleh atribut-atribut produk. Hal ini sesuai dengan pernyataan yang dikemukakan Craven (2003:9):

"Kepuasan konsumen dipengaruhi oleh identifikasi atribut produk baik secara pengiriman produk, performa produk atau jasa, citra perusahaan atau produk atau merek, nilai harga yang dihubungkan dengan nilai yang diterima konsumen".

Pendapat lain dari Supranto (2002:25) menyatakan bahwa pelanggan lebih memilih produk yang dibuat secara baik dan memiliki sederat fitur, keuntungan, dan jasa yang ditampilkan secara tepat sehingga pelanggan akan loyal/setia pada produk/jasa tersebut.

\subsection{Pengaruh Atribut Produk Terhadap Kepuasan Pelanggan Teh Celup 2 Tang}

Hasil perhitungan analisis data dari variabel atribut produk dan kepuasan pelanggan yang telah dilakukan, maka dapat diketahui bahwa atribut produk berpengaruh secara positif terhadap kepuasan pelanggan.

Dari hasil penelitian diperoleh angka koefisien korelasi 0,890 antara variabel atribut produk $(X)$ terhadap kepuasan pelanggan $(Y)$ memiliki hubungan yang termasuk kategori tinggi atau kuat (Sugiyono:2005:18). Selain itu, atribut produk memiliki pengaruh positif terhadap kepuasan pelanggan. Hal ini terbukti dengan hasil perhitungan koefisien determinasi yaitu dengan 
mengkuadratkan koefisien korelasi $\mathrm{r}^{2} \times 100 \%=$ $(0,890 \times 0,890) \times 100 \%$ diperoleh hasil sebesar 79,1 yang berarti bahwa perubahan variabel kepuasan pelanggan sebesar 79,1 dipengaruhi oleh atribut produk, sedangkan 20,9 dipengaruhi oleh faktor lain.

Adapun untuk mengetahui uji probabilitas atau uji pengambilan keputusan, maka dapat diketahui melalui tabel annova atau $\mathrm{F}$ test dimana

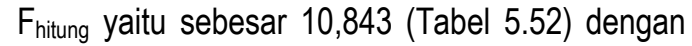
tingkat signifikansi sebesar 0,000 dan probabilitas $(0,000)$, sedangkan $F_{\text {tabel }}=4,018$ (lampiran iterpolasi), karena nilai $F_{\text {hitung }}>F_{\text {tabel }}$ maka dapat disimpulkan tolak $\mathrm{H}_{0}$. Artinya ada hubungan linier antara atribut produk terhadap kepuasan pelanggan. Hal ini dapat dilihat pada tabel sig 0,000 (Tabel 5.52) yang lebih kecil taraf signifikansi $5 \%$. Maka dapat dikatakan bahwa atribut produk berpengaruh terhadap kepuasan pelanggan. Walaupun demikian, jika pada proses uji koefisien regresi, ternyata konstanta dinyatakan tidak valid, maka koefisien regresi $(X)$ adalah valid, sehingga model persamaan regresi tetap dapat dipakai untuk memprediksi kepuasan pelanggan.

Pengambilan keputusan pengujin hipotesis dilakukan dengan membandingkan thitung dengan $t_{\text {tabel }}$ perhitungan uji signifikansi dengan menggunakan alpha 0,05 pada uji satu pihak dengan derajat kebebasan (dk) n-2 maka dk $=31$ diperoleh thitung dan $t_{\text {tabel }}$ dengan taraf kesalahan 0,05 . Berdasarkan ketentuan hipotesis diterima jika $t_{\text {hitung }}>t_{\text {tabel }}$ maka diketahui bahwa harga $t_{\text {hitung }}$ $>t_{\text {tabel }}(10,843>2,019)$ (Tabel 5.51) sehingga dapat disimpulkan bahwa koefisien korelasi antara variabel atribut produk terhadap kepuasan pelanggan memiliki hubungan yang signifikan.

Pernyataan tersebut diperoleh melalui pengujian hipotesis yang menggunakan metode regresi linier sederhana, ditunjukkan dengan perolehan kepuasan pelanggan dimana setiap penambahan 1 atribut produk akan meningkatkan kepuasan pelanggan yaitu sebesar 4,474 ditambah 0,942 dari atribut produk $(Y=4,474+$ $0,773 \mathrm{X})$, dimana koefisien determinasi $\left(\mathrm{r}^{2}\right)$ yaitu 0,890 termasuk kategori sangat kuat berada diantara $(0,80-1,000)$.

Koefisien korelasi yang bernili positif menunjukan jika perusahaan meningkatkan atribut produk maka dapat diprediksi bahwa kepuasan pelanggan akan naik. Namun, sebaliknya jika perusahaan tidak meningkatkan atribut produk maka kepuasan pelanggan bisa menurun.

Setelah melakukan pembelian, maka konsumen mengalami suatu tingkatan kepuasan atau ketidakpuasan. Kepuasan menunjukkan seberapa dekat harapan konsumen atas produk yang ditawarkan dan apa yang dirasakan dari produk tersebut yang diwakili oleh atribut-atribut produk. Hal ini sesuai dengan pernyataan yang dikemukakan Craven (2003:9):

"Kepuasan konsumen dipengaruhi oleh identifikasi atribut produk baik secara pengiriman produk, performa produk atau jasa, citra perusahaan atau produk atau merek, nilai harga yang dihubungkan dengan nilai yang diterima konsumen".

Pendapat lain dari Supranto (2002:25) menyatakan bahwa pelanggan lebih memilih produk yang dibuat secara baik dan memiliki sederat fitur, keuntungan, dan jasa yang ditampilkan secara tepat sehingga pelanggan akan loyal/setia pada produk/jasa tersebut.

\section{DAFTAR PUSTAKA}

Barnes, James (2003), Secret of Customer Relationship Management, Rahasia manajemen hubungan pelanggan, ANDI Yogyakarta.

Buchari Alma, (2004), Manajeman Pemasaran Barang dan Jasa, Bandung: Alfabeta.

Craven, David, W, (2003), Strategic Marketing, Sevent Edition, Boston: Irvin McGraw-Hill.

Fandy Tjiptono, (2002), Strategi Pemasaran, Yogyakarta: Penerbit Andi.

--ons), Brand Managemant Strategy,Yogyakarta: Penerbit Andi.

Harun Al Rasyid, (1994), Teknik Penarikan Sampel dan Penyusunan Skala, Bandung.

Husein Umar, (2002), etode penelitian dan Aplikasi dalam Pemasaran, Jakarta: PT Gramedia Pustaka.

Keller Kevin Lane, (2003), Building Measuring and Managing Brand Equity, New Jersey: Prentice Hall.

Kertajaya, Hermawan, (2002), Marketing Plus 2000 Siasat Memenangkan Persaingan Global, Jakarta: PT Gramedia Pustaka. 
Kotler dan Amstrong, (2006), Marketing Management, New Jersey: Prentice Hall.

Kotler, Philip, (2002), Manajeman Pemasaran Edisi Milenium. Jakarta: Prenhallindo.

Kotler, Philip, (2005), Manajeman Pemasaran Edisi Kesebelas, Jilid 2, Jakarta: PT Indeks Kelompok Gramedia.

Moh. Natsir, (1988), Metode Penelitian. Jakarta. Ghalia Indonesia.

Mowen and Michael Minor,(2002) Perilaku konsumen. Erlangga Jakarta

Nirwana Sk. Sitepu, (1994), Analisis Regresi dan Korelasi, Bandung: Unit Pelayanan Statistika FPMPA Unpad.

Rangkuty, Fredy, (2004), The Power of Brand, Jakarta: PT Gramedia Pustka.

Ratih Hurriyati, (2005), Bauran Pemasaran dan Loyalitas Konsumen, Bandung, Alfabeta

Stanton, William J dan Charles Futrell, (1994), Fundamental of Marketing 8 Th Edition. Singapura. Mc Grow Hill.

Sugiyono, (2005), Metode Penelitian Bisnis. Bandung:CV. Alfabeta.

Suharsimi Arikunto, (2002), Prosedur Penelitian Suatu Pendekatan Praktis, Jakarta: Rineka Cipta.

Supranto M.A.J, (2001), Pengukuran Tingkat Kepuasan Pelanggan, Jakarta: Rineka Cipta

Surakhmad Winarno.(1984). Metodologi Pengajaran Nasional. Jemmaps. Bandung

Majalah:

Marketing/ Edisi Khusus/ 1/ 2007

SWA 15/XX/21 Juli-3 Agustus 2006

SWA 19/XXI/15-28 September 2005

SWA/20/XXII/21 September - 4 Oktober 2006

Web site:

www.duatang.com

www.google.com

www.sosro.com

www.swa.co.id 